Burns, K. A. \& Smith, J. L. (1981). Biological monitoring of ambien water quality: the case for using bivalves as sentinel organisms for monitoring petroleum pollution in coastal waters. Estuar. Coast. Shelf Sci. 13, 433-443

Dou, Z. X., Huang, K. X. \& Zhang, C. Z. (1980). Numerical calculation of the tidal and residual current in the Bohai Sea. Haiyang Huanjing Kexue 1, 1-20.

Dou, Z. X., Huang, K. X. \& Zhang, C. Z. (1982). Tidal current-pollutants dispersion model. Haiyang Huanjing Kexue 1, 27-55.

Ehrhardt, M. (1981). Organic substances in the Baltic Sea. Mar. Pollut Bull. 12, 210-213.

El Samra, M. I. \& El Deeb, K. Z. (1988). Horizontal and vertical distribution of oil pollution in the Arabian Gulf and the Gulf of Oman. Mar. Pollut. Bull. 19, 14-18.

Fowler, S. W. (1985). Coastal baseline studies of pollutants in Bahrain, UAE and Oman. ROPME Symposium on Regional Marine Monitoring and Research Programmes, U.A.E. Univ. Al-Ain, 8-11 December, 1985

Gupta, R. S. \& Kureishy, T. W. (1981). Present State of oil pollution in the northern Indian Ocean. Mar. Pollut. Bull. 12, 295-301.

Law, R. J. (1981). Hydrocarbon concentrations in waters and sediments from UK marine waters by fluorescence spectroscopy. Mar. Pollut Bull. 12, 153-157.
Levy, E. M. (1971). The presence of petroleum residues off the east coast of Nova Scotia, in the Gulf of St. Lawrence, and the St. Lawrence river. Water Res. 5, 723-733.

Levy, E. M. \& Walton, A. (1976). High seas oil pollution: particulate petroleum residues in the Nroth Atlantic. J. Fish. Res. Bd Can. 33, 2781-2791

Liou, J. M. (1987). The study of controlling pollutants discharged into the coastal water. Haiyang Huanjing Kexue 6, 9-19.

Moore, J. W. \& Ramamoorthy, S. (1984). Organic Chemicals in Natural Waters. Springer-Verlag, New York.

Qu, C. Y. (1987). Optimal Selection of the Sampling Stations in the Bohai Sea. Institute of Marine Environmental Protection, Dalian, China.

Shang, L. S. (1988). Unpublished data, personal communication.

Shi, E. H., Han, J. G. \& Huang, S. G. (1982). Seawater pollution on the nearshore of China. Haiyang Huanjing Kexue 1, 13-27.

Standard Methods of Marine Pollution Investigation (1985). State Oceanic Administration, Oceanic Press.

Wan, Q. Z. (1986). Estimation and prevention policy of the oil spills in the marine environment. Haiyang Kexue 10, 55-57.

Yang, Q. X. (1986). Strategic Plan for Spilled Oil Pollution in the Marine Environment. Institute of Marine Environmental Protection, Dalian, China.

\title{
Application of the Mussel Watch Concept in Studies of Hydrocarbons, PCBs and DDT in the Brazilian Bay of Todos os Santos (Bahia)
}

\author{
T. M. TAVARES*, V. C. ROCHA*, C. PORTE $\dagger$, D. BARCELO $\dagger$ and J. ALBAIGÉS $\dagger$ \\ ${ }^{*}$ Department of Analytical Chemistry (UFBa) Instituto de Química, Campus Universitario Federaçao s/ $n$, \\ 40210 Salvador, BA, Brazil. \\ $\dagger$ Department of Environmental Chemistry (C.I.D.-C.S.I.C.), Jorge Girona, 18-26, 08034 Barcelona, Spain
}

\begin{abstract}
Data on aliphatic and aromatic hydrocarbons, PCBs, and DDT in different species of edible bivalves collected along the Todos os Santos Bay (Bahia, Brazil) are reported for the first time for the SW Atlantic coast. The species and collection sites were selected for the identification of suitable regional sentinels and the assessment of different coastal pollutant sources.

Anomalocandia brasiliana, the dominant and most frequent bivalve of the Brazilian coast, can be an adequate bioindicator because it accumulates organic pollutants with reasonable sensitivity.
\end{abstract}

The 'Mussel Watch' concept, that is, the utilization of sentinel organisms for monitoring the concentration of selected pollutants in coastal environments and as an indicator of their bioavailability, is gaining wide accept- ance and programmes are being established on a national as well as on an international level. To this end bivalves, especially mussels (Mytilus sp.) and oysters (Crassostrea sp. and Ostrea sp.) have been selected as the most useful marine indicator organisms due to their wide distribution and abundance in the temperate and subtropical zones, their general ability to bioaccumulate most pollutants, and their sedentary stationary habits, thus providing natural and temporal integrated levels of contaminants in coastal zones (Goldberg et al., 1978). Unfortunately, these species do not frequently occur in tropical waters where, as in other areas, strategies for monitoring pollution are required. This is the case of the Todos os Santos Bay, the largest on the Brazilian coast $\left(1000 \mathrm{~km}^{2}\right)$, situated at lat. $13^{\circ} \mathrm{S}$ (Fig. 1). The purpose of this study was to use this site as a case for gaining some knowledge about suitable sentinel organisms in tropical environments.

Since 1968, the area around the bay (Reconcavo) has 


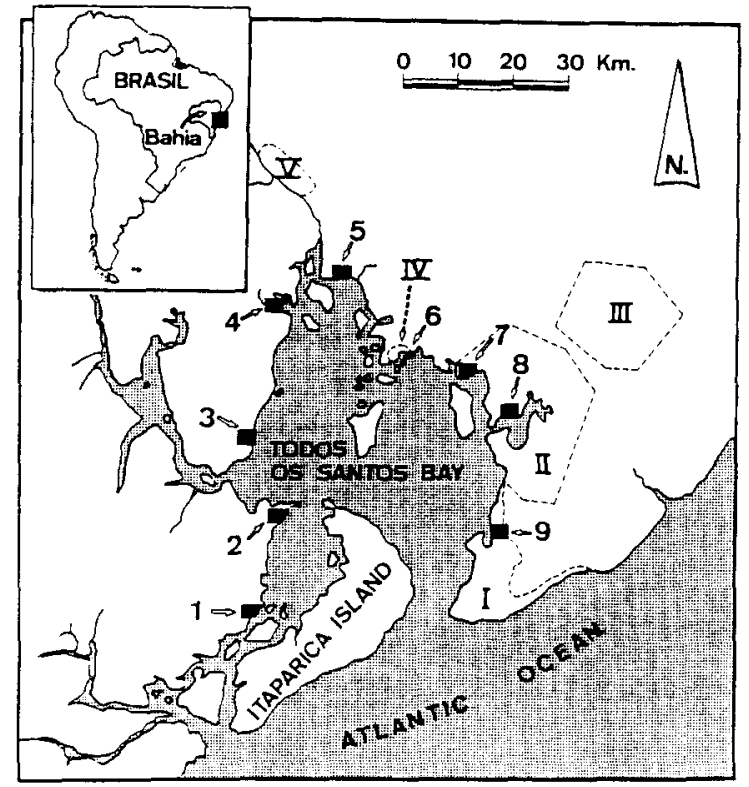

Fig. 1. Sampling sites in Todos os Santos Bay. I: Salvador City; II: industrial centre (AIC); III: Camacari petrochemical complex; IV: oil refinery; V: lead smelter, paper mills, alcohol distilleries.

been subject to increasing industrial growth together with an intense exploitation of its natural resources. Today this area consists in the second largest industrial park of the country, developed mainly to the north-east of the bay. In addition, the city of Salvador, which presently has 1.6 million inhabitants, dominantes the entrance of the bay (I in Fig. 1). Two ports, one at Aratú, only for industrial products, and the main one at Salvador are situated on the east coast of the bay.

The concurrence of these conflicting activities has prompted the establishment of pollution monitoring programmes in the area. However, these programmes have been restricted to inorganic substances, particularly heavy metals $(\mathrm{Hg}, \mathrm{Cd}$, and $\mathrm{Pb}$ ) in sediment and bivalves, and effects on the human population (Souza et al., 1978; Silva et al., 1981; Carvalho et al., 1984, 1985a, 1985b, 1986). In the present study, two main aspects were addressed, namely the assessment of the geographical distribution of hydrocarbons and chlorinated compounds in intertidal edible bivalves in the bay, and the selection of indicator organisms of organic pollution for the Brazilian tropical coast.

To the best of our knowledge this is the first study of this type carried out in the South Atlantic region.

\section{Materials and Methods}

Samples were collected always at low tide between September 1985 and January 1986. Individuals of medium size were selected for each bivalve species. Collected samples were wrapped in clean aluminium foil placed in styrofoam boxes with ice and brought to the laboratory on the same day. Immediately upon arrival they were sucked, drained and frozen in aluminium foil at $-18^{\circ} \mathrm{C}$.

All collected individuals of each species were pooled together and homogenized to obtain mean values of pollutant concentrations (Bernhard, 1976). Subsamples of the tissue homogenates (9-10 g) were treated as described by Albaigés et al. (1987): saponification of the homogenates ( $6 \mathrm{~N}$ aq. $\mathrm{NaOH}$ ), extraction (ethyl ether) of the total organic extract and further fractionation by liquid chromatography (5\% water deactivated silica-alumina) (Aceves et al., 1988).

The first fraction (alkanes +alkenes) was analysed by capillary GC-FID using a Carlo Erba Mod. 4160 GC, equipped with a fused silica column $(20 \mathrm{~m} \times 0.25 \mathrm{~mm}$ i.d. DB-5, J\&W Sci.) temperature programmed 60$300^{\circ} \mathrm{C}$ at $6^{\circ} \mathrm{C} \mathrm{min}^{-1}$. Resolved components and the unresolved complex mixture (UCM) were quantified by comparison with external standards (mixture of $n-C_{14}$, $\mathrm{n}-\mathrm{C}_{22}, \mathrm{n}-\mathrm{C}_{32}$, and $\mathrm{n}-\mathrm{C}_{36}$ ), using a Hewlett-Packard 9830-A microprocessor equipped with a digital planimeter.

The second fraction, containing DDT (in the DDE form due to the saponification of the homogenate) and PCBs, was analysed by $\mathrm{GC}{ }^{63} \mathrm{Ni}$ ECD (Carlo Erba FC $4130)$, using a capillary column $(30 \mathrm{~m} \times 0.25 \mathrm{~mm}$ i.d., SPB-5, Supelco) with hydrogen as carrier gas. Both analytes were quantified by using external standard solutions of $\mathrm{pp}^{\prime}-\mathrm{DDE}$ and a mixture of $\mathrm{PCB}$ s prepared from the following analytical reagant grade individual compounds (Promochem, Wesel, FRG): 2,4,4'trichlorobiphenyl (IUPAC No. 28); 2,5,2',5'tetrachlorobiphenyl (52); 2,4,5,2',5'-pentachlorobiphenyl (101); 2,4,5,3',4',5'-heptachlorobiphenyl (153) and $2,3,4,5,2^{\prime}, 4^{\prime} 5^{\prime}$-heptachlorobiphenyl (180). Confirmation of DDE and PCBs was accomplished by Negative Chemical Ionization Mass Spectrometry in a quadropole GC/MS (Hewlett-Packard Model 5888 A) using methane as reactant gas at $30 \mathrm{ml} \mathrm{min}^{-1}$ (2 Torr) (Porte et al., 1988).

The aromatic hydrocarbons in the second and the third fractions were analysed by means of UVfluorescence (Perkin-Elmer MPF-3). Aliquots of fractions II and III, irradiated at $310 \mathrm{~nm}$ (slit $20 \mathrm{~nm}$ ), had its fluorescence intensities measured at $360 \mathrm{~nm}$ using chrysene as standard.

\section{Results and Discussion}

Nine stations were selected for sampling according to the different environmental characteristics of the bay (Fig. 1). Stations 1-4, at the western side, were expected to reflect background levels of contamination because they correspond to rather pristine areas. The others (59 ), in the eastern part, were located near the industrial and urban zones.

After visiting the sites, a great variety of bivalve species were identified in the intertidal range. However, only one Anomalocardia brasiliana (fam. Veneridae), was found to be present in all of them. In fact, this species, which is a suspension feeder and lives buried in the upper $5 \mathrm{~cm}$ of sandy substrates, is the dominant and most frequent bivalve of the Brazilian coast (Peso, 1980). Another venerid Protothaca pectorina, was also found widely distributed, although not so much as Anomalocardia. Two species Lucina pectinata (fam. Lucinadae) and Macoma constricta (fam. Tellinidae) were abundant in certain restricted areas, probably due to some environmental constraints.

For comparative qualitative and quantitative pur- 
poses within species, extensive sampling was decided at site 7. Eight different species listed in Table 1 were collected, including Mactra fragilis which lives in the infralittoral zone.

The FID chromatograms of the corresponding alkane +alkene fractions (fraction I) clearly showed two different patterns. One, primarily associated to samples from stations $1-4$, consisted of a series of large and well resolved peaks, and another exhibited a more complex series of resolved peaks overlying an unresolved mixture of hydrocarbons (UCM). The study of the components by HRGC-MS revealed that these two patterns were dominated respectively by biogenic and petrogenic hydrocarbons (Albaigés et al., to be published). The latter include the series of regular acyclic isoprenoids, the unresolved complex mixture of alkanes (UCM) and, occasionally, the $\mathrm{C}_{15}-\mathrm{C}_{35} \mathrm{n}$ alkanes with carbon number preferences close to unity (CPI 1).

Based on these parameters, the levels of hydrocarbon pollution in bivalves of the Todos os Santos Bay were estimated and are indicated in Table 1. In general, the lower levels of UCM and high n-alkane CPI values, that is the less polluted samples, correspond to those collected at stations $1-4$, whereas concentrations up to $30-42 \mu \mathrm{g} \mathrm{g}^{-1}$ wet wt with CPI 1 were found in stations 5-6. Stations 7-9 exhibited an intermediate degree of contamination. The aromatic hydrocarbons showed a similar spatial trend. At this respect, it is worth noting that the concentrations of the UCM of alkanes, determined by gas chromatography, and the aromatic hydrocarbons, expressed in UV-fluorescence chrysene equivalents, exhibit a correlation coefficient of 0.956 . This suggests a similar bioaccumulation pattern of all species and also a common source for the two types of hydrocarbons. These data represent a moderate to low level of petroleum contamination in the bay, when compared with the levels reported for other coastal areas. Concentrations of UCM of alkanes in the range of $100-200 \mathrm{\mu g} \mathrm{g}^{-1}$ dry wt have been reported for mussels collected in bays and harbours of the US and Spanish Coasts, whereas concentrations below $10 \mu \mathrm{g}$ $\mathrm{g}^{-1}$ dry wt were found in relatively unpolluted areas (Farrington et al., 1983; Risebrough et al., 1983). Assuming a factor of 5 between dry and wet weights in mussels it appears that only stations 5 and 6 (Table 1) can be considered to be heavily contaminated.

Absolute values change from one species to another, although not very significantly. These differences cannot be attributed to variations in fat content because all bivalve species studied ranged between $0.9-1.1 \%$ wet wt. In any case the variation exhibited by the dominant species Anomalocardia brasiliana is geographically significant, reflecting the human activities existing around the bay and, thus, becoming a suitable sentinel organism for monitoring organic pollution in the area.

The concentrations of the organochlorinated compounds, p,p'-DDT (expressed as p,p-DDE) and PCBs (expressed as the sum of seven congeners) presented in Table 1, indicate very low levels of these components in the area.
The use of individual congeners for quantifying PCBs in environmental samples instead of PCB commercial mixtures, as in the present case, has received increasing attention (Tuinstra et al., 1985). Nevertheless, the large sets of data available on total PCBs require some guidance for comparison. At this respect, we have recently shown that concentrations of the individual congeners Nos. 28, 52, 101, 118, 138, 153 , and 180 can be intercompared, exhibiting a mean ratio among values of 3.17 with a correlation coefficient of 0.9984 (Porte et al., 1988). Taking this into consideration, the estimated levels of total PCBs in the present samples should reach a maximum of $30 \mathrm{ng} \mathrm{g}^{-1}$ dry wt, with most values below $10 \mathrm{ng}^{-1}$. As a reference, the lower values in samples from industrialized countries, are in the order of 8 and $14 \mathrm{ng} \mathrm{g}^{-1}$ dry wt of DDE and total PCBs, respectively (Risebrough et al., 1983).

Besides these low levels, the geographical patterns of PCBs and DDT are slightly different, the latter occuring at higher levels in station 5 and the former at stations $7-9$, possibly reflecting different input sources. It is also interesting to mention that the different species accumulate the selected PCB congeners in relatively similar proportions, thus facilitating the above intercomparison of data.

In summary, it can be concluded that the 'Mussel Watch' concept can be applied in tropical zones using alternative bivalve species as sentinel organisms. Preliminary data indicate that Anomalocardia brasiliana exhibit satisfactory response to local changes in pollutant inputs, although more data on the pollutant biodynamics of this organism is required.

This work has been carried out in the framework of the CNPq (Brasil) and C.S.I.C. (Spain) agreement of scientific cooperation.

Aceves, M., Grimalt, J., Albaigés, J., Broto, F., Comellas, L. \& Gassiot, M. (1988). Analysis of hydrocarbons in aquatic sediments. II Evaluation of common preparative procedures for petroleum and chlorinated hydrocarbons. J. Chromatog. 436, 503-509.

Albaigés, J., Farran, A., Soler, M., Gallifa, A. \& Martin, P. (1987). Accumulation and distribution of biogenic and pollutant hydrocarbons, PCBs and DDT in tissues of Western Mediterranean fishes. Mar. Environ. Res. 22, 1-18.

Bernhard, M. (1976). Manual of methods in aquatic environment research. Part 3. Sampling and analysis of biological material. FAO Fish Tech. Rep. 158.

Carvalho, F. M., Tavares, T. M., Linhares, P. \& Souza, S. P. (1984). Lead and Cadmium Concentration in the Hair of Fishermen from the Subaé River Basin, Brazil. Environ. Research 33, 300-306.

Carvalho, F. M., Tavares, T. M. \& Menezes, G. M. (1985a). Mercury in a Brazilian Population Eating Large Quantities of Shellfish Cient. Cult. 37, 2063-2066.

Carvalho, F. M., Silvany-Neto, A. M., Tavares, T. M., Lima, M. E. \& Waldron, H. A. (1985b). Lead Poisoning Amongst Children from Santo Amaro City. Brazil. PAHO Bulletin 19, 165-175.

Carvalho, F. M., Tavares, T. M., Silvany-Neto, A. M., Lima, M. E. \& Alt. F. (1986). Cadmium Concentrations in Blood of Children Living Near a Lead Smelter in Bahia, Brazil. Environ. Research 40, 437449.

Farrington, J. W., Goldberg, E. D., Risebrough, R. W., Martin, J. H. \& Bowen, V. T. (1983). U.S. 'Mussel Watch' 1976-1978: An overview of the trace-metal, DDE, $\mathrm{PCB}$, hydrocarbon and artificial radionuclide data. Environ. Sci. Technol. 17, 490-496.

Goldberg, E. D., Bowen, V. T., Farrington, J. W., Harvey, G., Martin, J. H., Parker, P. L., Risebrough, W., Schneider, E. \& Gamble, E. (1978). The mussel watch. Envir. Conserv. 5, 1-25.

Peso, M. C. (1980). Bivalves comestiveis de Bahia de Todos os Santos. M.Sc. Thesis. University of Paraná. Curitiba. Brasil. 
TABLE 1

Hydrocarbons ( $\mu \mathrm{g} \mathrm{g}^{-1}$ wet $\left.w t\right)$ and DDT and PCBs (ng g $\mathrm{g}^{-1}$ wet $\left.w \mathrm{t}\right)$ in bivalves of the Todos os Santos Bay.

\begin{tabular}{|c|c|c|c|c|c|c|c|c|c|c|}
\hline Species & Stations & 1 & 2 & 3 & 4 & 5 & 6 & 7 & 8 & 9 \\
\hline Anomalocardia brasiliana & $\begin{array}{l}a \\
b \\
c \\
d \\
e\end{array}$ & $\begin{aligned} & 0.3(3.5) \\
&< 0.1 \\
&< 0.1 \\
& 0.1 \\
& 0.2\end{aligned}$ & $\begin{array}{l}0.1(2.6) \\
0.5 \\
<0.1 \\
0.05 \\
\text { nd }\end{array}$ & $\begin{array}{l}0.5(4.1) \\
3.9 \\
0.2 \\
0.1 \\
0.06\end{array}$ & $\begin{array}{l}0.5(2.8) \\
1.9 \\
0.1 \\
0.05 \\
\text { nd }\end{array}$ & $\begin{array}{l}5.1(1.2) \\
19.8 \\
1.6 \\
1.2 \\
\text { nd }\end{array}$ & $\begin{array}{l}2.9(1.3) \\
26.0 \\
3.3 \\
0.4 \\
0.4\end{array}$ & $\begin{array}{l}0.6(1.7) \\
4.3 \\
0.5 \\
0.2 \\
0.3\end{array}$ & $\begin{array}{l}0.2(1.0) \\
5.5 \\
0.4 \\
0.05 \\
0.3\end{array}$ & $\begin{array}{l}1.4(1.6) \\
14.6 \\
0.4 \\
1.1 \\
0.3\end{array}$ \\
\hline Lucina pectinata & $\begin{array}{l}a \\
b \\
c \\
d \\
e\end{array}$ & $\begin{array}{l}0.2(6.3) \\
<0.1 \\
0.2 \\
0.4 \\
0.3\end{array}$ & $\begin{array}{l}0.1(1.5) \\
0.3 \\
0.1 \\
0.5 \\
0.2\end{array}$ & & $\begin{array}{l}0.3(3.7) \\
1.2 \\
0.2 \\
0.05 \\
\text { nd }\end{array}$ & & & & & \\
\hline Protothaca pectorina & $\begin{array}{l}\mathrm{a} \\
\mathrm{b} \\
\mathrm{c} \\
\mathrm{d} \\
\mathrm{e}\end{array}$ & & & $\begin{array}{l}0.6(2.2) \\
4.1 \\
1.1 \\
0.2 \\
\text { nd }\end{array}$ & $\begin{array}{l}- \\
- \\
\overline{0.4} \\
0.1\end{array}$ & $\begin{array}{l}0.9(1.2) \\
15.7 \\
3.5 \\
2.5 \\
0.6\end{array}$ & & $\begin{array}{l}3.8(4.2) \\
3.2 \\
0.3 \\
0.8 \\
1.1\end{array}$ & & $\begin{array}{l}0.3(1.8) \\
6.6 \\
0.3 \\
1.9 \\
0.9\end{array}$ \\
\hline Macoma constricta & $\begin{array}{l}\mathrm{a} \\
\mathrm{b} \\
\mathrm{c} \\
\mathrm{d} \\
\mathrm{e}\end{array}$ & & & & $\begin{array}{l}0.7(4.0) \\
2.5 \\
0.3 \\
0.3 \\
0.5\end{array}$ & $\begin{array}{l}3.0(1.3) \\
30.5 \\
3.2 \\
2.0 \\
0.6\end{array}$ & $\begin{array}{l}5.8(1.2) \\
42.0 \\
9.1 \\
0.4 \\
0.8\end{array}$ & & & \\
\hline Mytella falcata & $\begin{array}{l}a \\
b \\
c \\
d \\
e\end{array}$ & & & $\begin{array}{c}2.6(3.2) \\
<0.1 \\
0.3 \\
\text { nd } \\
\text { nd }\end{array}$ & & & & $\begin{array}{l}3.2(1.3) \\
2.4 \\
0.2 \\
\text { nd } \\
1.0\end{array}$ & & \\
\hline Crassostrea rhizophorae & $\begin{array}{l}a \\
b \\
c \\
d \\
e\end{array}$ & & & & & & & $\begin{array}{l}1.5(1.1) \\
5.8 \\
0.9 \\
0.2 \\
1.9\end{array}$ & & \\
\hline Pitar fulminata & $\begin{array}{l}\mathrm{a} \\
\mathrm{b} \\
\mathrm{c} \\
\mathrm{d} \\
\mathrm{e}\end{array}$ & & & & & & & $\begin{array}{l}8.0(1.4) \\
5.2 \\
0.6 \\
\text { nd } \\
2.1\end{array}$ & & \\
\hline Mactra fragilis & $\begin{array}{l}a \\
b \\
c \\
d \\
e\end{array}$ & & & & & & & $\begin{array}{l}0.2(1.2) \\
2.6 \\
0.2 \\
\text { nd } \\
1.4\end{array}$ & & \\
\hline Semele proficua & $\begin{array}{l}a \\
b \\
c \\
d \\
e\end{array}$ & & & & & & & $\begin{array}{l}1.6(1.4) \\
6.2 \\
0.7 \\
\text { nd } \\
1.4\end{array}$ & & \\
\hline Trachycardium muricatum & $\begin{array}{l}a \\
b \\
c \\
d \\
e\end{array}$ & $\begin{array}{l}\text { n-alk. (C) } \\
\text { UCM } \\
\text { arom. } \\
\text { DDT (as } \\
\text { PCBs ( } 7\end{array}$ & $\begin{array}{l}\text { PI) } \\
\text { DDE) } \\
\text { congeners) }\end{array}$ & & & & & $\begin{array}{l}1.1(2.3) \\
4.5 \\
0.5 \\
\text { nd } \\
0.2\end{array}$ & & $\begin{array}{l}22(1.2) \\
20.6 \\
0.5 \\
5.1 \\
2.1\end{array}$ \\
\hline
\end{tabular}

Porte, C., Barceló, D. \& Albaigés, J. (1988). Determination of total vs. selected $\mathrm{PCB}$ congeners in marine biota samples by HRGC with ECD and negative ion chemical ionization mass spectrometry detection. J. Chromatog, in press.

Risebrough, R. W., de Lappe, B. W., Walker, W., Simoneit, B. R. T., Grimalt, J., Albaigés, J., García, J. A., Ballester, A. \& Mariño, M. G. (1983). Application of the mussel watch concept in studies of the distribution of hydrocarbons in the coastal zones of the Ebro Delta. Mar. Pollut. Bull. 14, 181-187.

Silva, A. M. B. S., Tavares, T. M. \& Landim, H. B. (1981). Determina- tion of mercury in intertidal bivalves along the coast of the Todos os Santos bay. Supl. Cienc. Cult. 33, 519.

Souza, S. P., Tavares, T. M. \& Brandao, A. M. (1978). Distribution of lead, cadmium and zinc in sediments of the Subaé river estuary, Bahia. Supl. Cienc. Cult. 30, 406.

Tuinstra, L. G. M. Th., Roos, A. H., Griepink, B. \& Wells, D. E. (1985). Interlaboratory studies of the determination of selected chlorobiphenyl congeners with capillary GC using splitless and on-column injection techniques. $J$. High Resol. Chromatogr. \& GC 8, 475-480. 